
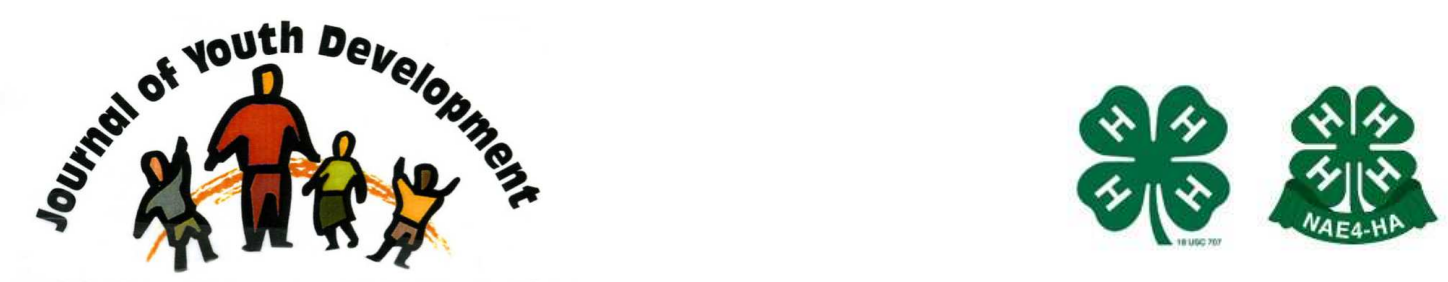

Bridging Research \& Practice

\title{
Building Civic Leadership: The Journeys of Pre-Adolescent Youth
}

\author{
Nicole Nicotera \\ Graduate School of Social Work \\ University of Denver \\ Denver, CO \\ nnicoter@du.edu
}

\author{
Dawn Matera Bassett \\ Department of Social Work \\ Metropolitan State University of Denver \\ Denver, CO \\ dmatera@msudenver.edu
}




\title{
JOURNAL OF YOUTH DEVELOPMENT \\ bridging research and practice

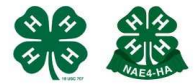

Volume 10, Number 1, Spring 2015

Article 151001FA002

\section{Building Civic Leadership: The Journeys of Pre-Adolescent Youth}

\author{
Nicole Nicotera \\ University of Denver \\ Dawn Matera Bassett \\ Metropolitan State University of Denver
}

\begin{abstract}
Studies of younger youth suggest that the path to civic leadership and the development of associated skills and attitudes is not linear. Instead, these studies suggest that as youth learn to act as agents of change, their real world experiences may create dissonance in their civic skills and attitudes. The reported current study employs qualitative methods to examine the experiences of urban, low-income, youth of color who participated in a civic leadership curriculum. Findings give voice to youth's experiences and the tension that can occur on their journeys toward civic leadership. Implications are discussed.
\end{abstract}

\section{Introduction}

Scholars propose that civic identity can be developed in youth if they are viewed as change agents who have the capacity to contribute to their communities (Rubin, 2007; Shiller, 2012). In fact, Checkoway and Gutierrez (2006) suggest that opportunities for community participation, such as civic leadership, allow youth to participate as assets in their communities and thus promote healthy developmental outcomes. Opportunities to engage as active members of a community are important for all youth and even more important for urban, lowincome, and minority youth. For example, due to experiences of marginalization, low-income youth and youth of color tend to be less civically engaged and may require different pathways to engagement than their white and/or more affluent counterparts (Atkins, \& Hart 2003; Balsano, 2005; Sanchez-Jankowski 2002; Torney-Purta, Barber, \& Wilkenfeld, 2006). This gap in civic engagement for marginalized youth suggests that it may be important to engage them in their pre-adolescent years as opposed to waiting until they reach high school (Balsano, Phelps, Theokas, Lerner, \& Lerner, 2009). 
Encouragingly, when pre-adolescents participate in projects intended to improve community conditions they can become civically engaged (Shiller, 2012). However, studies suggest that the path to civic leadership is not linear (RMC Research Corporation, 2005; 2006; Sullivan, 2006). Instead, these studies report that as youth learn to act as agents of change, their real world experiences may create dissonance in their civic skills and attitudes. The current reported study employs qualitative methods to further examine the civic journeys of urban, low-income, youth of color who participated in a civic leadership curriculum.

Empirical evidence on outcomes related to programs that promote civic leadership in preadolescent youth is limited. This dearth of evidence is understandable given the challenges of conducting research in community-based programs where attendance fluctuates and attrition is a fact of life (Israel, Schulz, Parker, \& Becker, 1998). However, the existing studies are instructive. For example, a case study of fifth-grade girls $(\mathrm{N}=5)$ who participated in a civic engagement program called Public Achievement (PA), reported growth in civic skills, efficacy, and knowledge over a 17-month period (Smith, 2012).

In contrast, a quasi-experimental study of PA, indicated mixed outcomes that appear to be agerelated (RMC Research Corporation, 2005; 2006). For example, the youngest participants (grades 2 and 3 ) reported less confidence about making the world a better place at post-test than those who were in a comparison group (RMC Research Corporation, 2005). However, 4th and 5th grade participants indicated greater affinity for willingness to solve problems at posttest than the students in a comparison group (RMC Research Corporation, 2006). These mixed outcomes are echoed in research on the Young Heroes, a program offered by City Year to youth ages 11 to 14 years old (Sullivan, 2006). Participants in that study demonstrated "high idealism about changing their communities, but at the program's end, their enthusiasm had receded below beginning levels" (Sullivan, 2006, p. ii). However, at a 6 month follow up the participants' attitudes had returned to the pre-test levels (Sullivan, 2006).

These mixed findings among pre-adolescent youth suggest that dissonance occurs on the path toward civic leadership. That is, studies indicate growth in some civic skills and attitudes simultaneous to a reduction in other civic capacities. This warrants further study to gain a better understanding of these complex journeys. The current qualitative study contributes to this endeavor by examining youth's civic attitudes as they spend four weeks collaborating with peers to evaluate conditions and create change in the urban, public housing neighborhoods where they reside.

The study explores the overarching research question,

What happens for youth who engage with peers to develop and apply civic leadership skills in the neighborhoods where they reside?

Hence, this study focuses on the ups-and-downs youth experience as they engage in civic activities as opposed to measuring the efficacy of a curriculum. This focus on understanding the journey aligns with Roholt, Baizerman, and Hildreth's (2013) assertion that researchers move from an emphasis of "changing [youth] to supporting them in understanding self, their community, and the larger world, as well as how they can change social conditions that negatively affect them" (p. 163).

\section{Study Context and Curriculum}

The civic leadership curriculum took place during four weeks of summer programming offered at a neighborhood-based afterschool program that focuses on increasing school success through mentoring, tutoring, and scholarship opportunities. The afterschool program is offered 
in several public housing neighborhoods in a western U.S. city. Youth who attend the program live at or below the poverty level, more than $70 \%$ of them receive free or reduced lunches at school and reside within or nearby the neighborhoods where each program site is located.

In addition to the civic leadership curriculum, the summer program provided supplemental reading groups, technology skills training groups, and a snack-recess period on Monday through Thursday with Fridays devoted to field trips. The civic leadership groups met 2 times per week, 1 hour for each session for a total of 8 hours over the 4 weeks. Attendance was quite regular as perfect attendance for all programming on Monday-Thursday was required for participation in the Friday field trips (e.g. amusement parks, movies, museums).

The civic leadership curriculum aimed to foster foundational civic skills and attitudes by providing hands-on learning opportunities for youth collaboration and leadership. The curriculum was developed from the ideas and activities of the international work of Driskell (2002) and Chawla (2002) as well as from aspects of the Public Achievement Project (Hildreth, 2000). Activities included a modified photo-voice approach (Wang, \& Burris, 1997) during which youth took photos in their neighborhoods, made written observations to assess the strengths and challenges of their respective neighborhoods and used this evidence to identify the problems or issues of most importance to them. The photo-voice approach was used because it has been shown to be effective in working with diverse groups to create needs assessments for social action (Wilson, Dasho, Martin, Wallerstein, Wang, \& Minkler, 2007).

In addition to the photo voice activities, the youth collaborated with each other and community resources such as urban gardens and graffiti trucks to plan and host neighborhood action days related to the problems they identified. The youth also developed fliers and canvassed the neighborhood to invite residents to the action days. Graduate student research assistants who had experience working with youth and community organizing facilitated each of the small groups. The principal investigator supervised the graduate students.

\section{Method}

\section{Participants}

Seventy-seven youth participated in the civic leadership curriculum and 57 of those youth were present for the focus groups. The focus group participants were between the ages of 8 and 13 years old $(\bar{X}$ age $=9.96, S D=1.5)$ and boys made up $52.6 \%(n=30)$ of the sample. The majority of the youth were Latino/a $(77.2 \%, \mathrm{n}=44)$, followed by African American youth $(10.5 \%, n=6)$, White youth $(8.8 \%, n=5)$, and Asian youth $(3.5 \%, n=2)$.

\section{Data Collection Protocol and Procedures}

All protocol and procedures were approved by the Institutional Review Board and parent consent and youth assent was obtained. Youth who were present on the first day and last day of summer programming participated in the focus groups. The protocol included questions to explore youth experiences with civic leadership and action. For example, during the initial focus groups youth were queried about their opinions on working with peers; what they thought about the idea of helping others (friends, family, people they did not know); what they thought kids could do to make change, and if they had aspirations for helping others in the present and future.

Additional questions were added for the final focus groups to learn about youth's experiences over the four weeks. For example, youth were asked their opinions on what they liked and did not like about collaborating with peers; what they had learned about themselves and working 
with others; what they learned about trying to make change in their neighborhoods; and who else, besides them, did they think should help to make changes in the neighborhood.

Focus groups lasted for about 30 to 45 minutes and were conducted by the graduate student research assistants. During the initial focus groups one site had a recording malfunction and no pre-focus group data were available for that site. The focus groups were intentionally structured to be fun, relaxing, and allow each participant the opportunity to share their views, as per Hill's (2006) findings on key factors children found to be important when involved with a research study.

\section{Results}

\section{Analysis}

The focus groups were transcribed, cleaned and loaded on to Atlas-ti for analysis. Lincoln and Guba's (1985) constant comparative method (CCM) was applied throughout analysis. In general, CCM involves analyzing data from the ground up by first coding actual words or phrases used by the participants (in-vivo codes) in order to capture the local language and ground the findings in the voices of the participants (Lincoln, \& Guba, 1985). Subsequent steps in CCM include:

a) examining in-vivo codes in order to group them by common properties to develop preliminary or low-level inference themes,

b) deeper analysis to ensure that preliminary themes cut across the data, and

c) further analysis to abstract up to higher-level inference themes (Boeije, 2002; Lincoln, \& Guba, 1985).

More specifically our analytic process involved 5 steps. During step 1, the two authors worked independently to analyze the data for in-vivo codes. Since one of the authors was not familiar with the related literature this strategy helped to decrease researcher bias. Step 2 involved the two authors comparing and contrasting their in-vivo codes to reach a consensus and group them into low-level inference themes (Seale, 1999 as cited in Silverman, 2006).

Step 3 included establishing the boundaries of the low-level inference themes by summarizing the rules or criteria by which data could be placed in one theme versus another (Boeije, 2002, Lincoln, \& Guba, 1985). Throughout this third step, each preliminary theme and related in-vivo codes were further compared directly to the data to ensure that they met the criteria we had established and that they were grounded in the voices of the participants (Boeije, 2002; Lincoln, \& Guba, 1985). The fourth step involved abstracting up to higher-level inference themes (Seale, 1999 as cited in Silverman, 2006) and further ensuring that they represented all the data and remained grounded in the voices of the youth.

The final step in our analysis involved quantifying the qualitative data in order to examine the percentages of quotes for each theme at initial and final focus groups. In order to make an accurate comparison of quote counts and themes between the initial and final focus groups we did not include the data from the site where the recording malfunction occurred. Atlas-ti allows for the quantification of qualitative data because it provides output of quote counts by theme into Excel files. The output from Atlas-ti displayed the total number of researcher-identified quotes in the initial and final focus group data respectively alongside of the count of quotes for each theme so that the number and percentage of quotes related to each theme could be assessed. This resulted in a nearly equal number of quotes in the initial focus groups $(N=256)$ and the final focus groups $(\mathrm{N}=254)$. 


\section{Findings}

Our analysis uncovered 10 themes across the initial and final focus groups: advocacy, agency, civic knowledge, and optimism about the goodness of others, mutuality, skills needed for cooperation, by-product of cooperation, aloofness, peers and conflict, and beneficial place (see Table 1). This section provides quotes to further delineate each theme with abbreviated theme definitions so as not to repeat the more detailed definitions in Table 1.

\section{Table 1}

Qualitative Findings

\begin{tabular}{|c|c|}
\hline Theme Label & Theme Description \\
\hline Advocacy & $\begin{array}{l}\text { Quotes that indicate active support of an idea or cause especially the act of } \\
\text { making a case or arguing for something. This may be found in the discussion of } \\
\text { the participant advocating for self or others or the discussion of others in the act } \\
\text { of advocacy as defined above. }\end{array}$ \\
\hline Agency & $\begin{array}{l}\text { Quotes that reference to actions or power taken or planned to take by the } \\
\text { participants or others to affect the community, affect others, or influence their } \\
\text { own lives. This could also include a product or result or a consequence of } \\
\text { someone's efforts or a particular set of circumstances. Agency may have a positive } \\
\text { or negative valence, i.e., agency can have a socially positive result or a socially } \\
\text { negative result. Agency is different than one-to-one interactions where one youth } \\
\text { tells another youth to "stop it." }\end{array}$ \\
\hline $\begin{array}{l}\text { Aloof-Self } \\
\text { Aloof-Other }\end{array}$ & $\begin{array}{l}\text { Quotes that indicate an absence of a sense of agency, or that indicated a sense of } \\
\text { detachment, or a disconnection from a civic response as observed in self or } \\
\text { others. When the youth is the actor aloof was labeled Aloof-Self. When the youth } \\
\text { is the observer aloof was labeled as Aloof-Other. }\end{array}$ \\
\hline $\begin{array}{cl}\text { Beneficial Place } \\
\circ & \text { Modify } \\
\circ & \text { Create } \\
\circ & \text { Maintain }\end{array}$ & $\begin{array}{l}\text { Quotes that indicate the desire to have a better place through modifying what } \\
\text { exists in the neighborhood, creating new resources in the neighborhood, or } \\
\text { maintaining what already exists. This may be a specific statement about what } \\
\text { needs to be changed or what a youth does not like in the neighborhood (Modify) } \\
\text { or a general statement about what they wish was in the neighborhood (Create) or } \\
\text { what they want to maintain or preserve that they like in the neighborhood } \\
\text { (Maintain). }\end{array}$ \\
\hline $\begin{array}{l}\text { By-product of } \\
\text { Cooperation }\end{array}$ & $\begin{array}{l}\text { Quotes that indicate a result or consequence of cooperating with peers. For } \\
\text { example, cooperating with peers resulted in getting the job done more quickly. }\end{array}$ \\
\hline Civic Knowledge & $\begin{array}{l}\text { Quotes that indicate youth know how society works (or does not work). These } \\
\text { may include governmental or non-governmental systems as well as when youth } \\
\text { talk about public issues such as elections. }\end{array}$ \\
\hline Mutuality & $\begin{array}{l}\text { Quotes that indicate a reciprocal relationship between interdependent entities; any } \\
\text { time when the youth mention positive reciprocity. }\end{array}$ \\
\hline $\begin{array}{l}\text { Optimism about the } \\
\text { goodness of others }\end{array}$ & $\begin{array}{l}\text { Quotes that indicate the belief or view that helping is what people "ought to do" } \\
\text { or that people will help if called upon. This is in reference to others, NOT the } \\
\text { youth themselves. The youth is the observer of the action or has the perception } \\
\text { that others will help. }\end{array}$ \\
\hline Peers and Conflict & $\begin{array}{l}\text { Quotes that indicate conflict experiences with peers whether it was talking about } \\
\text { fights, or not getting along with others, noting that others don't always want to do } \\
\text { things the way the speaker wants them to, or disagreements happening between } \\
\text { the youth during the focus group that require redirection by the facilitator. }\end{array}$ \\
\hline $\begin{array}{l}\text { Skills Needed for } \\
\text { Cooperation }\end{array}$ & $\begin{array}{l}\text { Quotes that indicate basic skills needed for cooperation including the ability to } \\
\text { assess the characteristics or qualities of others or the ability to assess the } \\
\text { characteristics or qualities of self whether or not the assessment is social } \\
\text { desirable. Skills Needed for Cooperation may occur between peers or between a } \\
\text { youth and an adult. }\end{array}$ \\
\hline
\end{tabular}


Agency, Advocacy, and Civic Knowledge. The theme agency, represents focus group discussions about actions the youth wanted to take or had taken to affect the community, other people, or their own lives, regardless of whether this action had positive or negative outcomes. This theme is closely tied to the theme, advocacy, which was applied when youth actively supported or argued for an idea. The following quote depicts these two themes as one of the youth presents and argues for his idea on how to help the homeless, "See, make them a little shelter where people work there and give them food, clothes - hand-me-down clothes, not real clothes." Another youth noted the agency and advocacy themes during a conversation about changing the problem of trash in the neighborhood when she stated that she would stand up to someone littering and ask them to stop and put it in the trash can. The agency theme also appears on its own in the following quote where a youth describes the type of action one could take, noting that it could be for positive or negative ends "You could help somebody steal or like help somebody build something."

The theme, civic knowledge, reflects quotes in which youth describe how civil society works (or does not work). These include references to how governmental or non-governmental systems could help or hinder their civic efforts as well as when youth talk about public issues such as elections. This theme often arose in conversations related to agency such as the following quote:

Adult: How do you guys think kids can help to make change in the neighborhood?

Youth 1: Go see the mayor.

A: Kids can go to the mayor?

Y2: Write a note.

Y3: Send a letter.

Y4: Signing all, then the mayor will see the president and the president will pass a new law.

A: Who should be the one help them?

Y5: The police, the government.

Y6: The police are never around.

Note that the last two youth speaking in this quote exemplify the notion that civic knowledge includes knowledge about how civil society helps and hinders action, i.e., when asked who should help one youth states, "the police, the government" (how civil society works) and the other responds, "the police are never around" (how civil society does not work).

Optimism about the Goodness of Others and Mutuality. While the youth in this study described experiences of the police not being around when they are needed, they still believe that helping is something that people "ought to do" or that others will help if called upon. The theme, optimism about the goodness of others represents this view as depicted in the following quote:

A: If someone in your neighborhood asked for help, who would be the one to help them?

Y1: Us

Y2: Teachers

Y3: Everyone

Y4: Some people don't get along but put aside their differences to help each other - to help the neighborhood. 
In addition to this optimism or belief that others will help, the youth described their understanding and practice of reciprocity, the idea that people can benefit from interdependent relationships as represented by the theme mutuality and portrayed in the following quotes. The first quote represents a proximal view of mutuality: "I want to help my family because now they've helped me some and I want to help them some." However, the second quote represents a broader or more distal view of mutuality:

Y: "What did I learn working with other kids? That like Martin Luther King made a dream and his dream came true, and his dream should still be true, that all of us, all of the little black boys and little black girls and all little white boys and all little white girls coming outside to play with each other and helping out each other when needed."

Skills Needed for Cooperation and the By-product of Cooperation. In addition to the previous themes, the focus group discussions portrayed the theme, skills needed for cooperation. This theme was represented by quotes in which they described their capacity to cooperate or that they at least knew the basic skills needed to cooperate with others, even if they weren't always able to implement them. The skills for cooperation also included youth's ability to assess their own skills and the characteristics of others. The following quote represents this theme as the youth assess their own behavior, noting that they act in ways that are not conducive to cooperation while simultaneously demonstrating they know what skills are needed for cooperation, even if they can't quite act them out.

A: What don't you like about working with other kids?

Y1: I don't like to fight with them.

Y2: Um, I don't like to say mean words to them.

Y3: I don't like to say bad things to my friends.

A: What about other people who aren't your friends?

Y3: I just ignore them.

Y4: I don't like when they punch me.

A: What don't you like working together with other kids?

Y5: I don't like when they are teasing me and I don't like when I'm teasing them.

Even though cooperation wasn't always easy for the youth they noted that there is a benefit to working with others and these quotes are represented by the theme, by-product of cooperation. A: What do you like about helping other kids?

Y1: I like helping other kids because if you help other kids then they will help you back, and then you can help others, you can help some more kids.

Y2: If you help like if you and some other kids help you can talk to each other and you may learn new stuff with them and get the job done faster.

Peers and Conflict and Aloofness. The next two themes represent the obstacles youth experienced along their civic leadership journeys. The theme peers and conflict portrays the challenges youth experienced as they endeavored to collaborate. In the following quote a youth simply points out that when people get tired, conflict occurs: "They got tired, they got in a fight." Other youth provided a more complex view of the theme, peers and conflict:

Y: "What's hard, some of us cannot get along well and some of us interrupt. Like when there are new kids around, we're not showing the new kids a good example and when there are new kids around we are supposed to be good children, supposed to give them a good example to help them for when they stay here for a couple of days or years they'll know not to act like us when we were kids."

Y: "This boy he brings out his boxing gloves out 'cause he wants to fight with me but he doesn't want to hurt his fists and then he has an older brother put them on me and 
makes me fight him and then his older brother gets mad because I beat him up because I'm older and he's younger and I keep telling him don't fight me, don't punch me or I'll go mad."

Another obstacle to engagement is depicted in the theme aloof. This theme represents discussions the youth had that reflected the absence of a sense of agency, a sense of detachment, or a disconnection within themselves (aloof-self) or as observed in others (aloofothers). The conversation below represents aloof as it applies to a youth herself and also demonstrates how youth observe aloofness in others.

A: How do you think kids could help to make changes in their neighborhoods?

Y1: I don't know. [aloof-self]

Y2: I don't want to help 'cause I don't like my school, I don't like my teachers. [aloof-self]

Y3: I don't understand why if there are trash bins, why they don't just throw them [beer cans] in it. [aloof-other]

Y4: People not putting it in the trash can and people not caring about it. [aloof-other]

In reference to the conversation quoted above, it is important to mention that responding, $I$ don't know, to a question about how youth can make change did not always correlate with an aloof attitude because sometimes, youth truly are not sure what they can do to create change. However, in the context of the focus group, this quote and tone indicated aloofness versus lack of knowledge about how to make change.

Beneficial Place. The last theme, beneficial place, arose from focus group discussions in which the youth described their desire to:

1) retain positive elements that already exist in the neighborhood (beneficial placemaintain);

2) modify what already exists in the neighborhood (beneficial place-modify), or

3) create new resources (beneficial place-create).

The next two quotes represent examples of what the youth would like to maintain in their neighborhoods:

Y: "Well, I like that there is a playground and there is a park so that way kids don't have to be bored and there is a recreation center that they can go to and they can join sports and clubs and all that."

Y: "[I like that there are] People that put the trash in the trash-can and people that solve problems."

These next two quotes depict what youth would like to modify about their neighborhoods:

Y: "You should pick up glass because people could get cut their feet cut and it could get infected and they can get sick."

Y: "Paint the park different colors, make it colorful."

Youth also shared ideas of new resources to create as the following quote portrays.

Y: "Starting today, I'm going to make my own business after [names afterschool program] for like retired people who can't walk and stuff, if they have to go to the store I'm gonna go for them so they can be better 'cuz a lot of people just a lot of old people never go out because there's whole bunch of fights outside my house and my mom don't like it because she has a feeling that they're going to pull out a gun." 
In addition to representing the theme beneficial place-create, the quote above brings us back to the themes agency and advocacy, as the youth describes the actions he wants to take to affect others and he argues for why this action is needed.

The Journey. This next set of findings represents the changes in the quote percentages by each qualitative theme from the initial to the final focus groups (see Table 2).

Table 2

Comparison of percentage of quotes for each theme at initial and final focus groups*

\begin{tabular}{|c|c|c|}
\hline Theme & $\begin{array}{l}\text { Initial } \\
\text { Quotes }\end{array}$ & Final Quotes \\
\hline Advocacy & $3.12 \% \quad(n=8)$ & $11.02 \% \quad(n=28)$ \\
\hline Agency (positive) & $\begin{array}{l}29.29 \% \\
(n=75)\end{array}$ & $29.52 \% \quad(n=75)$ \\
\hline Agency (negative) & $2.73 \% \quad(n=7)$ & $3.54 \%$ \\
\hline Aloof-Self & $\begin{array}{l}5.85 \% \\
(n=15)\end{array}$ & $(n=14)$ \\
\hline Aloof-Other & $2.73 \% \quad(n=7)$ & $(n=21)$ \\
\hline Beneficial Place (modify) & $\begin{array}{l}13.67 \% \\
(n=35)\end{array}$ & $15.34 \% \quad(n=39)$ \\
\hline Beneficial Place (create) & $1.95 \% \quad(n=5)$ & $1.18 \%$ \\
\hline Beneficial place (maintain) & $1.56 \% \quad(n=4)$ & $(n=13)$ \\
\hline By-product of Cooperation & $\begin{array}{l}10.15 \% \\
(n=26)\end{array}$ & $3.54 \%$ \\
\hline Civic Knowledge & $\begin{array}{l}8.2 \% \\
(n=21)\end{array}$ & $(n=25)$ \\
\hline Mutuality & $\begin{array}{l}6.64 \% \\
(n=17)\end{array}$ & $3.93 \% \quad(n=10)$ \\
\hline $\begin{array}{l}\text { Optimism about the } \\
\text { goodness of others }\end{array}$ & $\begin{array}{l}11.32 \% \\
(n=29)\end{array}$ & $10.23 \% \quad(n=26)$ \\
\hline Peers and Conflict & $\begin{array}{l}8.2 \% \\
(n=21)\end{array}$ & $7.48 \% \quad(n=19)$ \\
\hline $\begin{array}{l}\text { Skills needed for } \\
\text { cooperation }\end{array}$ & $\begin{array}{l}8.98 \% \\
(n=23)\end{array}$ & $19.68 \% \quad(n=50)$ \\
\hline
\end{tabular}

*Total quotes in initial-focus groups $=256$; total in final-focus groups $=254$; the data from the finalfocus group at the site where initial-focus group data are missing is not counted in this table. Total sum of quotes by columns in the table is larger because some quotes represent more than one theme.

As presented in Table 2, some of themes showed a near steady state with almost no difference in percentage of quotes per theme from initial to final focus groups, while others showed a decrease in percentage at the final focus groups, and still others indicated an increased representation at the final focus groups. Figure 1 provides a graphic depiction of this journey with the blue lines indicating a steady state or almost no difference between the initial and final focus groups; the green lines indicate an increased percentage of a quotes per theme at the final focus group and the red lines indicate a decreased percentage of quotes per theme at the final focus group. 
Figure 1

Depiction of initial and final focus group quote percentages

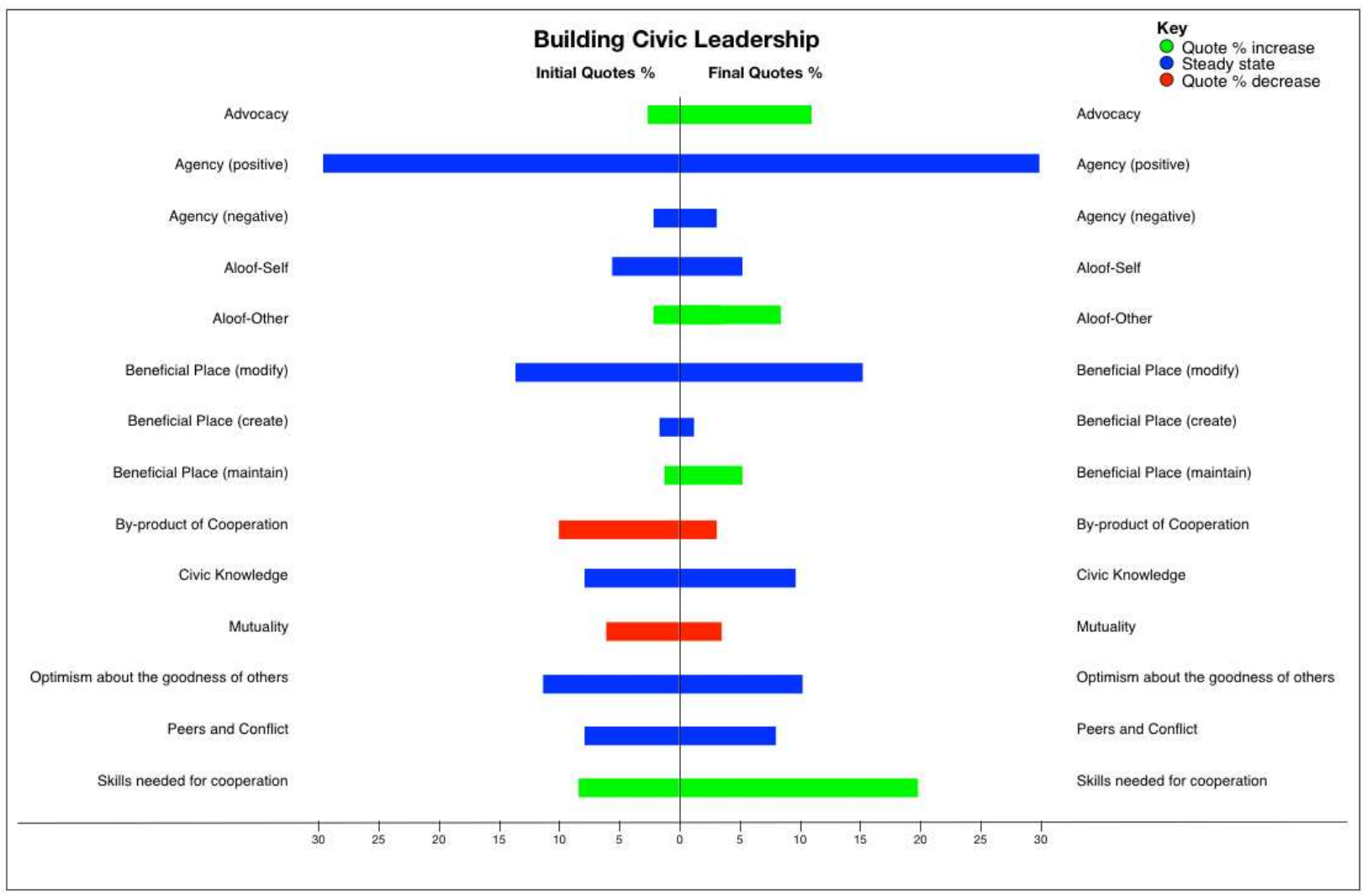

For example, percentage of quotes related to the theme depicting youth's perception of their own aloofness [aloof-self] was nearly the same (blue line) in the initial focus groups (5.85\%) as it was at the final focus groups (5.51\%). Similarly, the theme, optimism about the goodness of others, was nearly equal in the initial focus groups (11.32\%) and final focus groups $(10.23 \%)$. In contrast, the percentage of quotes related to the theme mutuality decreased in percent (red line) from the initial focus groups $(6.64 \%)$ to the final focus groups $(3.93 \%)$. Other themes such as advocacy and skills needed for cooperation showed an increased percentage (green line) of representation at the final focus groups. For example, percentage of quotes related to advocacy was smaller at the initial focus groups (3.12\%) than at final focus groups (11.02\%).

\section{Discussion}

This study explored the question, What happens for youth who engage with peers to develop and apply civic leadership skills in the neighborhoods where they reside? The findings illustrate the ups and downs that these youth experienced on the path toward civic leadership. The following discussion examines the findings in light of youth's journeys as agents of change and the dissonance inherent that journey.

The findings illuminate the youth's civic leadership journeys. For example, the percentage of quotes related to the theme advocacy increased at the end of the four week leadership curriculum, while there was almost no change in the percentage of quotes for the theme, agency. This suggests that over the course of the program the youth maintained their initial 
sense of agency, but advanced in advocacy. In contrast, youth's perspective on how much others would be willing to help make change decreased as illuminated by increased percentage of quotes for the theme, aloof-others. Examples of this were evident in final focus group discussions when youth indicated a greater awareness of people tossing beer cans in the alley versus the trash bin and when they expressed disappointment that some neighborhood residents did not attend the neighborhood action days that they held at the end of the summer. These findings suggest that youth learned that not everyone in a neighborhood is willing to act or to help, but also suggests an increase in their capacity to observe and assess qualities in others, such as an aloof attitude.

Additionally, as the youth discovered more things in their neighborhoods they liked and wanted to maintain [beneficial place maintain] they may have been more disappointed when they observed that others did not share their call to advocacy. These findings may shed light on the dissonant experiences of participants in the Young Heroes program who initially reported "high idealism about changing their communities, but at the program's end, their enthusiasm had receded below beginning level" (Sullivan, 2006, p. ii). The hope one can draw from the current study lies in the participants' maintained sense of agency and increased sense of advocacy over the program period.

Considered together, the findings suggest how a person of any age might assess her or his capacities and experiences after working collaboratively to make change. That is, people often enter community or other change efforts with a sense of agency, advocacy, and aspirations for mutuality. However, while change efforts are rewarding, they are also wrought with challenges that affect one's experiences and attitudes. Indeed, the findings suggest that this could be one possible story for the youth in our study. Their sense of agency at the end of the program was retained and they portrayed greater endorsement of a sense of advocacy. In contrast, at the end of the program, the youth assessed that indeed there was less reciprocity and mutuality among peers than they imagined prior to their collaborative change efforts.

Additionally, the findings suggest another experience common to organizing for change and this is the challenge of reaching out to neighborhood residents who did not always respond. These findings may illuminate the experiences reported by the participants studied in the Public Achievement program who indicated less confidence about making the world a better place at the end of programming (RMC Research Corporation, 2005, 2006).

It is noteworthy that throughout the journey the youth did not become more disengaged, i.e., the preponderance of the theme, aloof-self, is nearly the same at the initial and final focus groups. This is similar to the $4^{\text {th }}$ and $5^{\text {th }}$ grade participants in the Public Achievement program who indicated greater affinity for willingness to solve problems at the end of programming (RMC Research Corporation, 2005).

\section{Limitations}

Several limitations are at work in our study. While missing data is a fact of life in research, it does present limitation in this research. As noted earlier, a recording malfunction resulted in the absence of data for one of the sites at the initial focus group. However, all 10 themes were present whether we included or excluded the data from the final focus group for which we had no initial focus group recording. Also, the quote count and percentage comparisons were completed only for sites on which we had both initial and final focus groups. 
Also, during the 4 weeks of the curriculum the participants were also involved in other program activities such as technology-computer training, summer reading groups, and assorted field trips. While the other program activities did not intentionally seek to provide the same experiences as the civic leadership curriculum, it is feasible that some of the findings reported here are by-products of those activities or a combination of them and the leadership curriculum. However, the results paint a picture of youth experiences with civic leadership that highlights findings of other studies (RMC Research Corporation, 2005, 2006; Smith, 2012, Sullivan, 2006).

\section{Implications}

In sum, the findings suggest that participants' developed an awareness regarding the complexities of their neighborhoods and of working with peers and adults to effect change. In the words of Roth and Brooks-Gunn (2003) the curriculum provided the youth with "real challenges and active participation" (p. 204) and this resulted in real world findings that mirror real world experiences of civic leadership. The reality that civic engagement is a combination of positive and negative experiences is important learning for all civic leaders so that they may understand that working for change and engaging others in that change is challenging, but that it can also engender optimism.

The ups and downs of collaborative change efforts that the youth in our study experienced are instructive for practitioners who endeavor to implement civic leadership curricula. For example, youth may increase their sense that others are aloof to their cause and this can be an important point of discussion along their journey as change agents. Additionally, practitioners can help youth to recognize that the path to working for change includes many tough problems to solve and that no one is expected to always know how to solve them. Practitioners are encouraged to highlight the ups and downs which historical and contemporary civic leaders have experienced so that youth don't lose heart in their own process of leading.

Balsano (2005) states that "for most youth, civic engagement requires a personal transformation and we need to accept the responsibility of aiding youth through that transformation" (p. 199). Our findings and those of other studies on civic engagement programs with similar aged youth echo this idea of a journey versus an outcome. Practitioners are encouraged to support youth as they carve their pathways toward civic leadership and action.

\section{References}

Atkins, R., \& Hart, D. (2003). Neighborhoods, adults, and the development of civic identity in urban youth. Applied Developmental Science, 7, 156-164.

Balsano, A. (2005). Youth civic engagement in the United States: Understanding and addressing the impact of social impediments on positive youth and community development. Applied Developmental Science, 9(4), 188-201.

Balsano, A., Phelps, E., Theokas, C., Lerner, J.V., \& Lerner, R.M. (2009). Patterns of early adolescents' participation in youth developing programs having positive youth development. Journal of Research on Adolescence, 19(2), 249-259.

Boeije, H. (2002). A purposeful approach to the constant comparative method in the analysis of qualitative interviews. Quality and Quantity, 36, 391-409. 
Chawla, L. (2002). Growing up in an urbanizing world. London: Earthscan.

Checkoway, B., \& Gutierrez, L. (2006). Youth participation and community change Binghamton.

Driskell, D. (2002). Creating better cities with children and youth. London: Earthscan

Publications.

Hildreth, R. (2000). Theorizing citizenship and evaluating public achievement. PS: Political Science and Politics, 33(3), 627-632.

Hill, M. (2006). Children's voices on ways of having a voice: Children's and young people's perspectives on methods used in research and consultation. Childhood, 1, 69-89.

Israel, B., Schulz, A., Parker, E., \& Becker, A. (1998). Review of community-based research: assessing partnership approaches to improve public health. Annual Review of Public Health, 19, 173-202.

Lincoln, Y., \& Guba, E. (1985). Naturalistic inquiry. London: Sage Publications.

RMC Research Corporation. (2005, October). Public Achievement Evaluation Report. Minneapolis, MN: Center for Democracy and Citizenship, Humphrey Institute of Public Affairs.

RMC Research Corporation. (2006, October). Public Achievement Evaluation Report.

Minneapolis, MN: Center for Democracy and Citizenship, Humphrey Institute of Public Affairs.

Roholt, V., Hildreth, R., \& Baizerman, M., (Eds.). (2013). Engaging spaces: Opening spaces for civic youth development. Chicago, IL: Lyceum Books.

Roth, J., \& Brooks-Gunn, J. (2003). What exactly is a youth development program? Answers from research and practice. Applied Developmental Science, 7, 94-111.

Rubin, B. (2007). "There's Still Not Justice": Youth Civic Identity Development Amid Distinct School and Community Contexts. The Teachers College Record, 109(2), 449-481.

Sanchez-Jankowski, M. (2002). Minority youth and civic engagement: The impact of group relations. Applied Developmental Science, 6(4), 237-245.

Shiller, J.T. (2012). Preparing for democracy: How community-based organizations build civic engagement among urban youth. Urban Education, 48(1), 69-97.

Silverman, D. (2006). Interpreting qualitative data: Methods for analyzing talk, text, and interaction. (3rd edition). London: Sage Publications.

Smith, R. (2012). Set charge about change: The effects of a long-term youth civic engagement program. Journal of Community Engagement and Scholarship, 5(2), 48-60.

Sullivan, T. (2006). Becoming citizens and transformative civic leaders. Washington, DC: City Year Inc. Retrieved from http://www.cityyear.org/researchstudies.aspx July 13, 2011. 
Torney-Purta, J., Barber, C., \& Wilkenfeld, B. (2006). Differences in the civic knowledge and attitudes of U.S. adolescents by immigrant status and Hispanic background. Prospects (a UNESCO journal), 36(3), 343-354.

Wang, C., \& Burris, M. (1997). Photovoice: Concept, methodology, and use for participatory needs assessment. Health Education \& Behavior, 24(3), 369-387.

Wilson, N., Dasho, S., Martin, A.C., Wallerstein, N., Wang, C.C., \& Minkler, M. (2007). Engaging young adolescents in social action through photovoice: The youth empowerment strategies (YES!) project. Journal of Early Adolescence, 272), 241-261.

(C) Copyright of Journal of Youth Development $~$ Bridging Research and Practice. Content may not be copied or emailed to multiple sites or posted to a listserv without copyright holder's express written permission. Contact Editor at: patricia.dawson@oregonstate.edu for details. However, users may print, download or email articles for individual use.

ISSN 2325-4009 (Print); ISSN 2325-4017 (Online) 